\title{
Interferon-Gamma (IFNg) +874A/T Polymorphism Does Not Significantly Affect the Severity of Periodontitis
}

\author{
Chaerita Maulani $^{1} \quad$ Elza Ibrahim Auerkari ${ }^{2}$ Sri Lelyati C. Masulili ${ }^{3} \quad$ Lindawati S. Kusdhany ${ }^{4}$ \\ Yuniarti Soeroso $^{3}$ Nurtami Soedarsono ${ }^{2}$
}

${ }^{1}$ Faculty of Dentistry, Universitas Indonesia, Jakarta, Indonesia

2 Department of Oral Biology, Faculty of Dentistry, Universitas

Indonesia, Jakarta, Indonesia

${ }^{3}$ Department of Periodontology, Faculty of Dentistry, Universitas

Indonesia, Jakarta, Indonesia

${ }^{4}$ Department of Prosthodontics, Faculty of Dentistry, Universitas

Indonesia, Jakarta, Indonesia

\begin{abstract}
Address for correspondence Elza Ibrahim Auerkari, DRG, M.Biomed, SpOF(K), Department of Oral Biology, Faculty of Dentistry, Universitas Indonesia, Jl. Salemba Raya 4 No. 2, Jakarta 10430, Indonesia (e-mail: elza.ibrahim@ui.ac.id).
\end{abstract}

Eur J Dent 2022;16:327-332.

\section{Abstract \\ Keywords \\ - genetic polymorphisms \\ - interferon-gamma \\ - periodontitis}

Objectives Interferon-gamma (IFNg) is an immune-regulatory cytokine with a role in host responses to periodontitis. Genetic factors have been reported to modify the corresponding protein expression. The objective of this study was to evaluate the association and role of IFNg polymorphisms, such as IFNg $+874 \mathrm{~A} / \mathrm{T}$, and the susceptibility to periodontitis.

Materials and Methods A total of 100 unrelated subjects were included in the present study. Genomic deoxyribonucleic acid (DNA) was obtained from peripheral blood of 43 patients with mild periodontitis and 57 patients with severe periodontitis. The determined clinical parameters of periodontitis included probing depth, clinical attachment loss, and papilla bleeding index. The oral hygiene indicators were also assessed. The level of IFNg was determined from the gingival crevicular fluid by enzyme-linked immunosorbent assay technique. The IFNg $+874 \mathrm{~A} / \mathrm{T}$ polymorphisms were analyzed from peripheral blood by the method of restriction fragment length polymorphism-polymerase chain reaction.

Statistical Analysis Statistical analysis of the results was conducted using chi-squared testing for categorical data. Independent $t$-tests and Mann-Whitney $U$ tests were used for numeric data. Kruskal-Wallis testing was used to compare genotypes concerning for IFNg $+874 \mathrm{~A} / \mathrm{T}$ polymorphism. A $p$-value $<0.05$ was assumed for statistical significance.

Results Analysis of the IFNg $+874 \mathrm{~A} / \mathrm{T}$ polymorphism showed no significant differences with the level of IFNg. No significant differences were observed either in IFNg $+874 \mathrm{~A} / \mathrm{T}$ polymorphism between the subjects with mild periodontitis and those with severe periodontitis ( $p>$ 0.05 ). The subjects with severe periodontitis showed marginally but not significantly higher levels of IFNg compared with subjects with mild periodontitis $(p>0.05)$.

Conclusion The polymorphism of IFNg $+874 \mathrm{~A} / \mathrm{T}$ was not associated with the level of IFNg nor with the risk of periodontitis in this study. published online November 16, 2021
DOI https://doi.org/ $10.1055 / \mathrm{s}-0041-1735434$ ISSN $1305-7456$ (c) 2021. The Author(s).

This is an open access article published by Thieme under the terms of the Creative Commons Attribution License, permitting unrestricted use, distribution, and reproduction so long as the original work is properly cited. (https://creativecommons.org/licenses/by/4.0/)

Thieme Medical and Scientific Publishers Pvt. Ltd., A-12, 2nd Floor, Sector 2, Noida-201301 UP, India 


\section{Introduction}

Periodontitis is a multifactorial disease initiated by dental plaque. The bacterial agents in the dental plaque induce inflammatory reactions of the host immune system, leading to gingival inflammation that can further escalate to loss of dental attachment and finally loss of mandibular bone in untreated patients. Periodontitis is common, with a prevalence of $74.1 \%$ in Indonesia ${ }^{1}$ and 40.0 to $77.5 \%$ worldwide in the adult population. ${ }^{2-5}$

The genetic status of the host has an important effect on the pathogenesis of periodontitis. Genetic factors such as polymorphisms can stimulate or retard the production of specific cytokines. ${ }^{6}$ Previous studies have indicated pro- or anti-inflammatory polymorphisms in cytokine genes such as

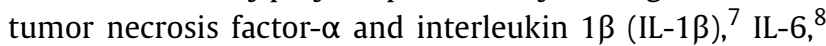
transforming growth factor- $\beta,{ }^{9}$ IL-10, ${ }^{10,11}$ and interferongamma (IFNg), ${ }^{12,13}$ also concerning periodontitis.

IFNg is one of the key cytokines regulating immune reactions. IFNg is secreted by CD4+ Th1 cells, CD8 cytotoxic cells, activated natural killer cells, and macrophages. ${ }^{13}$ The level of IFNg is elevated in diseased periodontal tissue and related to the severity of periodontitis. ${ }^{14,15}$

The IFNg gene is located at $12 \mathrm{q} 15$ and contains 4 exons. ${ }^{16}$ Single nucleotide polymorphism at $+874 \mathrm{~A} / \mathrm{T}$ (rs2430561) at the end of 5 '-CA is repeated at first intron related to changes of IFNg expression. ${ }^{17}$ The allele of $+874 \mathrm{~T}$ is linked to the 12 CA repeats, and the $A$ allele is connected to the non-12 CA repeats. ${ }^{18}$ The $\mathrm{T}$ allele-specific sequence binding to the transcription factor of nuclear factor kappa B (NFkB). NFkB induces IFNg expression, so the $+874 \mathrm{~T}$ allele is associated with high IFNg expression. ${ }^{19}$ A study in mice with the disruption of IFNg presented migration inflammatory cell and receptor activator of nuclear factor $\mathrm{K} \beta$-ligand levels in periodontium significantly decreased in bone resorption compared with wild-type mice. ${ }^{20}$ Another study has found that the production of IFNg in human peripheral blood CD4+ $\mathrm{T}$ cells produces IFNg as a response to IL-12 and IL-18, but also in the absence of any antigenic stimulation. ${ }^{21}$

This study aims to investigate the IFNg $+874 \mathrm{~A} / \mathrm{T}$ polymorphic genotypes in Indonesian subjects, comparing patients with severe and mild periodontitis and the level of IFNg.

\section{Materials and Methods}

\section{Patient Selection}

All subjects with or without periodontitis were collected from three subdistricts in central Jakarta $(n=100)$ from June 2018 to March 2019. The study was approved by the Research Ethics Committee of the Faculty of Dentistry Universitas Indonesia, protocol number 070390418 . The inclusion criteria were male and female $\geq 18$ years old, at least with 14 remaining teeth, in good general health. Exclusion criteria were current pregnancy and lactation, previous periodontal treatment within 6 months, use of antibiotics or immunosuppressant medication within the last 3 months, and inability or unwillingness to provide informed consent. All subjects provided written informed consent.

\section{Clinical Examination}

The diagnosis of periodontitis was based on an intraoral examination, bleeding on probing, probing depth, assessments of clinical attachment loss using University of North Carolina-15 probe (UNC-15 periodontal probe) Hu-Friedy (Chicago, IL, United States), tooth mobility, number of remaining teeth in all fully erupted teeth except third molars. The clinical parameters were examined by calibrated periodontists. Probing depth was measured from the gingival margin to the bottom of the pocket, and clinical attachment loss measured from the cementoenamel junction to the bottom of periodontal pocket assessed in six sites (distobuccal, buccal, mesiobuccal, mesiopalatal/lingual, palatal/lingual, distopalatal/lingual). The diagnostic criteria were based on the severity of periodontitis by the 2017 World Workshop on the Classification of Periodontal and Periimplant Diseases and Conditions staging. ${ }^{22}$ The case and control selection were based on clinical attachment loss $\geq$ $5 \mathrm{~mm}$ with probing depth $\geq 6 \mathrm{~mm}$ as severe periodontitis (periodontitis stage 3 and stage 4 ) and mild periodontitis when clinical attachment loss $<5 \mathrm{~mm}$ with probing depth $<6 \mathrm{~mm}$ (periodontitis stage 1 and stage 2 ).

\section{Subgingival Sample Collection}

IFN-g was retrieved from the gingival crevicular fluid by sterile paper point (International Organization for Standardization [ISO] 30, Roeko, Langenau, Germany). Each subject used four paper points in four regions in the deepest pocket and randomly in the healthy periodontal sulcus. The supragingival plaque was gently cleaned before sampling with sterile cotton pellets and isolated with cotton rolls. The paper point was inserted gently to the bottom of the selected pocket for 30 seconds All four paper points were pooled together in one tube with $1 \mathrm{~mL}$ phosphate buffer saline and transferred to the laboratory. In the laboratory, the samples were centrifuged for $\sim 20$ minutes at $1,000 \mathrm{~g}$ (or $3000 \mathrm{rpm}$ ) $\sim 30$ minutes after collection. The supernatant was collected carefully, and samples were stored immediately at $-20^{\circ} \mathrm{C}$.

\section{Blood Sample Collection and DNA Extraction}

Peripheral blood sample collected with vacutainer with ethylenediaminetetraacetic acid $\sim 3 \mathrm{~mL}$ by phlebotomists at the time of periodontal examination. The blood was stored in $-20^{\circ} \mathrm{C}$ until deoxyribonucleic acid (DNA) extraction. The genomic DNA was extracted using standard proteinase $\mathrm{K}$ digestion and salt purification method. ${ }^{23}$

\section{Interferon-Gamma Detection}

IFNg was detected by enzyme-linked immunosorbent assay kit (MyBioSource, San Diego, California, United States) according to the manufacturer's instructions. Briefly, $50 \mu \mathrm{L}$ of standard reagent was added to each standard well and $50 \mu \mathrm{L}$ of the sample to each sample well. Adding sample diluent $50 \mu \mathrm{L}$ to each black/control well, $20 \%$ of the samples were duplicated. The Horseradish peroxidase-conjugate reagent was added $100 \mu \mathrm{L}$ to each well, then covered with a closure plate membrane and incubated for 60 minutes at $37^{\circ} \mathrm{C}$. The plate was then washed four times. Chromogen 
solution was added to each well, then protected from light and incubated for 15 minutes at $37^{\circ} \mathrm{C}$. After adding stop solution of $50 \mu \mathrm{L}$ to each well, the color in the wells changed from blue to yellow. Finally, the optical density was read using Universal Microplate Reader (Sunrise, Tecan, Austria) at $450 \mathrm{~nm}$ within 5 to 15 minutes after adding the stop solution. The IFNg level was determined by comparing it with the standard curve. The detection range was from 31.2to $1,000 \mathrm{pg} / \mathrm{mL}$, but the lowest standard diluted twice so the final detection range was from 7.8 to $1,000 \mathrm{pg} / \mathrm{mL}$. The detected samples of more than $1,000 \mathrm{pg} / \mathrm{mL}$ or out of range were diluted and re-examined. The final measurement was multiplied by the number of dilutions.

\section{Polymorphism Detection}

The genomic DNA was extracted from peripheral blood leucocytes. IFNg $+874 \mathrm{~A} / \mathrm{T}$ polymorphism was evaluated by restriction fragment length polymorphism-polymerase chain reaction (RFLP-PCR) methods, described previously by Zambon et al. ${ }^{24}$ The IFNgA/T was amplified using forward primer: 5'-GATTTTATTCTTACAACACAAAATCAAGAC-3' and reverse primer: 5'-GCAAAGCCACCCCACTATAA-3'. PCR products $(176 \mathrm{bp})$ were digested with the Hinfl enzyme at $37^{\circ} \mathrm{C}$ for 1 hour and $65^{\circ} \mathrm{C}$ for 20 minutes. The restriction fragment separation ( $176 \mathrm{bp}$ for allele A, $148 \mathrm{bp}$, and $28 \mathrm{bp}$ for allele $\mathrm{T}$ ) was by electrophoresis at $70 \mathrm{~V}, 400 \mathrm{~mA}$ for 40 minutes on $1.5 \%$ agarose gel and staining with ethidium bromide.

\section{Statistical Analysis}

FNg allele frequencies were tested with Hardy-Weinberg equilibrium for both groups (patients and controls) using the chi-squared test. The significant association between periodontitis and IFNg genotypes was made using the chisquared test and Fisher's exact test. The relative risk of periodontitis associated with a particular genotype was estimated by the odds ratio (OR). The clinical parameters of periodontitis, comparison between IFNg level and periodontitis, comparison between IFNg level and IFNg genotypes were analyzed by Mann-Whitney $U$ or Independent $t$ test. Kruskal-Wallis test was used to assess a correlation between polymorphs of IFNg $+874 \mathrm{~A} / \mathrm{T}$ and the levels of IFNg. All statistical tests were performed using the SPSS software (IBM version 23, SPSS, Armonk, New York, United States). The two different groups were tested for significance by twotailed tests. A $p$-value $p<0.05$ was considered statistically significant.

\section{Results}

A total 100 subjects were included in the study with demographic data presented in - Table 1. The subjects with severe periodontitis have a higher median age than the subjects with mild periodontitis (47 [17] and 25 [15], respectively). The clinical parameters of periodontitis are shown in - Table 2. All parameters except the oral hygiene index showed statistically significant differences between patients with mild and severe periodontitis $(p<0.05)$.

The agarose gel electrophoresis results of the RFLP analysis for IFNg $+874 \mathrm{~A} / \mathrm{T}$ polymorphism are shown in - Fig. 1. The expected fragment sizes are for genotype AA $176 \mathrm{bp}$; for TT $148 \mathrm{bp}$ and $28 \mathrm{bp}$; and for AT $176 \mathrm{bp}$, $148 \mathrm{bp}$, and $28 \mathrm{bp}$.

Table 1 Demographic data and periodontal status of the subjects

\begin{tabular}{|c|c|c|c|}
\hline Variables & $\begin{array}{l}\text { Mild periodontitis } \\
(n=43) n(\%)\end{array}$ & Severe periodontitis $(n=57) n(\%)$ & $p$-Value \\
\hline Age, median (IQR) & $25(15)$ & $47(17)$ & 0.000 \\
\hline \multicolumn{4}{|l|}{ Sex $(P)$} \\
\hline Male & $39(57.4)$ & 29 (42.6) & 0.000 \\
\hline Female & $4(12.5)$ & $28(87.5)$ & \\
\hline $\mathrm{BMI}($ mean \pm SD) & $24.04 \pm 4.87$ & $25.80 \pm 4.04$ & 0.051 \\
\hline \multicolumn{3}{|l|}{ Education } & 0.055 \\
\hline Above high school & $9(64.3)$ & $5(35.7)$ & \\
\hline High school & $29(44.6)$ & $36(55.4)$ & \\
\hline Below high school & $5(23.8)$ & $16(76.2)$ & \\
\hline \multicolumn{3}{|l|}{ Occupation } & 0.113 \\
\hline Working & $33(49.3)$ & $34(50.7)$ & \\
\hline Not working & $10(30.3)$ & $23(69.7)$ & \\
\hline \multicolumn{3}{|l|}{ Smoking status } & 0.050 \\
\hline Nonsmoker & $21(34.4)$ & $40(65.6)$ & \\
\hline Smoker & $22(56.4)$ & $17(43.6)$ & \\
\hline
\end{tabular}

Abbreviations: BMI, body mass index; IQR, interquartile range; SD, standard deviation.

Note: Chi-square test. 
The chi-squared test showed that genotype frequencies of IFNg polymorphism were in Hardy-Weinberg equilibrium $(p$ $>0.05)$.

The distribution of the IFNg genotypes and allele frequencies for patient and control groups is shown in - Table 3. There were no significant differences between genotypes and alleles of the IFNg $+874 \mathrm{~A} / \mathrm{T}$ polymorphism between patients with mild and severe periodontitis $(p>0.05)$.

The comparison level of IFNg in mild and severe periodontitis is presented in - Table 4. - Fig. 2 illustrates the association between genotype IFNg $+874 \mathrm{~A} / \mathrm{T}$ and IFNg level, $p=0.155$ or no statistically different $p>0.05$. Categoric

Table 2 Clinical parameters of periodontitis

\begin{tabular}{|l|l|l|l|}
\hline & Mild periodontitis $(\boldsymbol{n}=\mathbf{4 3})$ & Severe periodontitis $(\boldsymbol{n}=\mathbf{5 7})$ & $\boldsymbol{p}$-Value \\
\hline Number of teeth $^{\mathrm{a}}$ & $26.30 \pm 2.18$ & $23.98 \pm 3.568$ & 0.001 \\
\hline Plaque index $^{\mathrm{a}}$ & $1.12 \pm 0.439$ & $1.32 \pm 0.390$ & 0.018 \\
\hline Papilla bleeding index $^{\mathrm{a}}$ & $1.06 \pm 0.608$ & $1.51 \pm 0.751$ & 0.001 \\
\hline Oral hygiene index $^{\mathrm{a}}$ & $2.15 \pm 0.830$ & $2.47 \pm 0.824$ & 0.061 \\
\hline Pocket depth $^{\mathrm{a}}$ & $1.59 \pm 0.292$ & $2.04 \pm 0.515$ & 0.000 \\
\hline Clinical attachment loss $^{\mathrm{a}}$ & $1.70 \pm 0.348$ & $2.80 \pm 0.774$ & 0.000 \\
\hline Tooth mobility $^{\mathrm{a}}$ & $0.00 \pm 0.000$ & $1.45 \pm 2.80$ & 0.000 \\
\hline
\end{tabular}

${ }^{a}$ Mann-Whitney $U$ test.

bIndependent $t$-test.

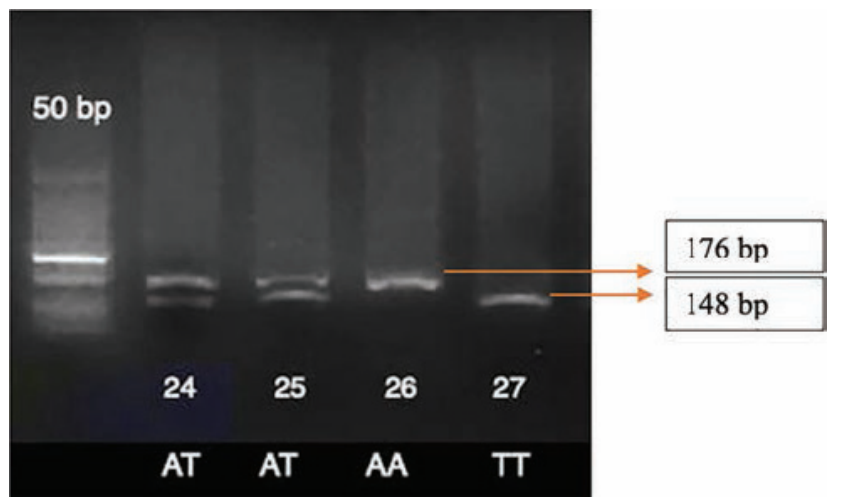

Fig. 1 Agarose gel electrophoresis of the restriction fragment length polymorphism analysis for interferon-gamma874 polymorphism: lane 1 shows a 50 bp ladder, lanes 2-5 are samples. The restriction fragment length was $176 \mathrm{bp}$ for allele A, 148 and $28 \mathrm{bp}$ for allele T.

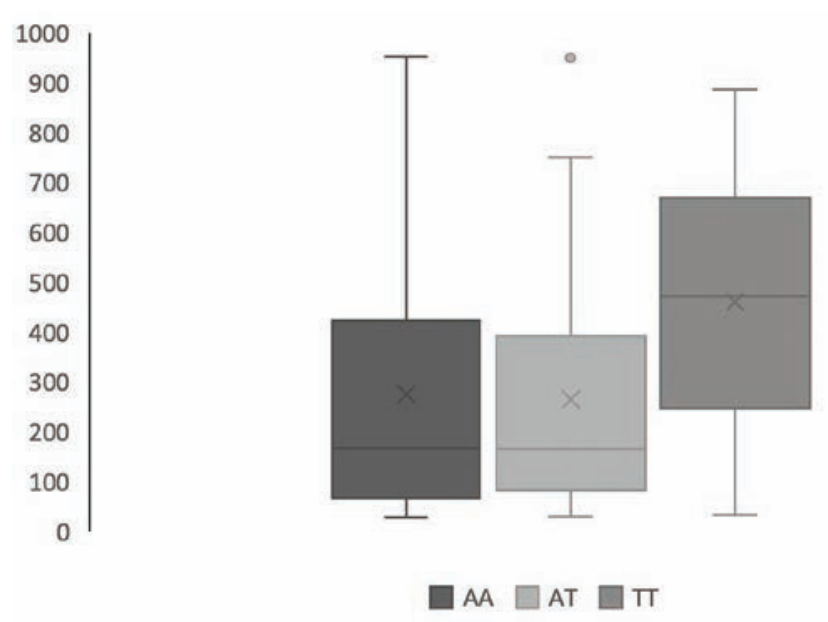

Fig. 2 Association between genotypes of interferon-gamma (IFNg) and IFNg level $(\mathrm{pg} / \mathrm{mL}), p>0.05$.

Table 3 Distribution of genotypic and allelic frequencies IFNg $(+874 \mathrm{~A} / \mathrm{T})$ in periodontitis

\begin{tabular}{|c|c|c|c|c|}
\hline & Mild periodontitis, $n=43(\%)$ & Severe periodontitis, $n=57$ (\%) & $p$-Value & OR $(95 \% \mathrm{Cl})$ \\
\hline \multicolumn{5}{|c|}{ Genotype } \\
\hline AA & $19(44.2)$ & $20(35.1)$ & & 1 \\
\hline AT & $20(46.5)$ & $31(54.4)$ & 0.37 & $1.47(0.63-3.42)$ \\
\hline TT & $4(9.3)$ & $6(10.5)$ & 0.62 & $1.43(0.35-5.85)$ \\
\hline \multicolumn{5}{|l|}{ Allele } \\
\hline A & $58(67.44)$ & $71(62.28)$ & & 1 \\
\hline $\mathrm{T}$ & $28(32.56)$ & $43(37.72)$ & 0.45 & $1.26(0.69-2.26)$ \\
\hline \multicolumn{5}{|c|}{ Dominant } \\
\hline $\mathrm{AA}$ & $19(44.2)$ & $20(35.1)$ & & 1 \\
\hline $\mathrm{AT}+\mathrm{TT}$ & $24(55.8)$ & 37 (64.9) & 0.36 & $0.68(0.30-1.54)$ \\
\hline
\end{tabular}

Abbreviations: $\mathrm{Cl}$, confidence interval; IFNg, interferon-gamma; OR, odds ratio.

Note: Chi-squared test. 
Table 4 Level of IFNg in mild and severe periodontitis as measured by ELISA

\begin{tabular}{|l|l|l|l|l|}
\hline Interferon-gamma & $\begin{array}{l}\text { Mild periodontitis } \mathrm{pg} / \mathrm{mL} \\
(\boldsymbol{n}=\mathbf{4 3 )}\end{array}$ & $\begin{array}{l}\text { Severe periodontitis } \mathrm{pg} / \mathrm{mL} \\
(\boldsymbol{n}=\mathbf{5 7})\end{array}$ & Detection range $\mathrm{pg} / \mathrm{mL}$ & $\boldsymbol{p}^{-V a l u \mathrm{e}^{\mathrm{a}}}$ \\
\hline Mean $\pm \mathrm{SD}$ & $229.76 \pm 189.15$ & $322.92 \pm 289.02$ & $15.6-1,000$ & 0.255 \\
\hline Median (IQR) & $158.46(250.40)$ & $215.50(541.64)$ & & \\
\hline
\end{tabular}

Abbreviations: ELISA, enzyme-linked immunosorbent assay; IQR, interquartile range; SD, standard deviation.

${ }^{a}$ Mann-Whitney $U$ test.

dominant genotype (AA vs. AT + TT) also not showed an association with the level of $\operatorname{IFNg}(p>0.05)$ as seen from - Table 5 .

\section{Discussion}

Periodontitis is a complex multifactorial disease that typically has a relatively mild phenotype, slowly progressing and chronic in nature. Periodontitis contributed to the global burden of disease with a prevalence of $25.4 \%$ and manifest in many systemic diseases. ${ }^{25,26}$ Genetic and environmental factors affect individual phenotypes in complex diseases. The genetic polymorphism in some situations may cause a change in protein that leads to a change in innate and adaptive immunity. ${ }^{27}$ Some single nucleotide polymorphisms were associated with severe chronic periodontitis. ${ }^{11}$ Meta-analysis study about periodontitis and IFNg $+874 \mathrm{~A} / \mathrm{T}$ showed the inconsistency of the results of $+874 \mathrm{~A} / \mathrm{T}$ polymorphism and periodontitis risk that may be attributed to several factors such as race, type of periodontitis, study design, and environmental factors. The limited study about $+874 \mathrm{~A} / \mathrm{T}$ polymorphism makes the research in the Asian population important to map the polymorphism accurately. ${ }^{28}$

In this study, there was no association between IFNg level and $+874 \mathrm{~A} / \mathrm{T}$ polymorphism which in line with previous studies found no significant correlation for alleles and genotypes between periodontitis and controls..$^{6,8,9,13,29}$ On the contrary, Heidari et al showed a significant association for IFNg $+874 \mathrm{~A} / \mathrm{T}$ polymorphism between patients with chronic periodontitis and controls. ${ }^{12}$ The IFNg $+874 \mathrm{~A} / \mathrm{T}$ polymorphism showed different distribution in Asia. Allele A showed low frequency in periodontitis patients, ${ }^{6}$ while in this study we found allele T in low frequency.

Table 5 Relationship between dominant genotypes of IFNg $+874 \mathrm{~A} / \mathrm{T}$ and IFNg level

\begin{tabular}{|l|l|l|}
\hline Dominant genotype & $\begin{array}{l}\text { Median (min-max) } \\
(\mathrm{pg} / \mathrm{mL})\end{array}$ & $p$-Value \\
\hline Dominant & & 0.623 \\
\hline AA $(n=39)$ & $166.8(27.6-952.3)$ & \\
\hline AT and TT $(n=61)$ & $190.3(29.9-950.0)$ & \\
\hline Recessive & & 0.054 \\
\hline TT $(n=10)$ & $471.2(33.1-885.8)$ & \\
\hline AA and AT $(n=90)$ & $165.9(27.6-952.3)$ & \\
\hline
\end{tabular}

Abbreviation: IFNg, interferon-gamma.

aMann-Whitney U test; detection range $15.6-1000 \mathrm{pg} / \mathrm{mL}$.
IFNg has an essential role as a proinflammatory agent, which influences the initiation and progression of periodontal disease. The T-allele of the IFNg $+874 \mathrm{~A} / \mathrm{T}$ polymorphism found increased production of this cytokine. This finding was confirmed in a previous study where the AA group was showing significantly lower production of IFNg than the AT group $(p<0.05) .^{30}$

Nonsignificant associations may arise because genetic variation may be a risk factor for a disease in one population but not in some other populations. The genotype and allele frequencies are varying between ethnically and geographically distinct populations. ${ }^{31}$

\section{Conclusions}

IFNg $+874 \mathrm{~A} / \mathrm{T}$ polymorphism was not significantly associated with the IFNg level of the gingival crevicular fluid of the tested periodontitis patients. There was also no significant association between the polymorphic genotypes and the severity of periodontitis when categorized as mild or severe.

\section{Funding}

This work was supported by Universitas Indonesia (grant number: BA1072/UN2.RST/PPM.00.03.01/2020) to E.I.A.

Conflict of Interest

None declared.

\section{References}

1 Kemenkes, Riskesdas 2018, Departemen Kesehatan RI. 2018: Jakarta. Accessed December 20, 2020 at: http://labdata.litbang. kemkes.go.id/images/download/laporan/RKD/2018/Laporan_Nasional_RKD2018_FINAL.pdf

2 Botelho J, Machado V, Proença L, et al. Study of Periodontal Health in Almada-Seixal (SoPHiAS): a cross-sectional study in the Lisbon Metropolitan Area. Sci Rep 2019;9(01):15538

3 Eke PI, Borgnakke WS, Genco RJ. Recent epidemiologic trends in periodontitis in the USA. Periodontol 2000 2020;82(01):257-267

4 Petersen PE, Ogawa H. The global burden of periodontal disease: towards integration with chronic disease prevention and control. Periodontol 2000 2012;60(01):15-39

5 Sekino S, Takahashi R, Numabe Y, Okamoto H. Current status of periodontal disease in adults in Takahagi, Japan: a cross-sectional study. BMC Oral Health 2020;20(01):60

6 Loo WT, Fan CB, Bai LJ, et al. Gene polymorphism and protein of human pro- and anti-inflammatory cytokines in Chinese healthy subjects and chronic periodontitis patients. J Transl Med 2012;10 (Suppl 1):S8

7 Lavu V, Venkatesan V, Venugopal P, et al. Clinical relevance of cytokines gene polymorphisms and protein levels in gingival 
cervical fluid from chronic periodontitis patients. Iran J Immunol 2017;14(01):51-58

8 Ianni M, Bruzzesi G, Pugliese D, et al. Variations in inflammatory genes are associated with periodontitis. Immun Ageing 2013;10 (01):39

9 Erciyas K, Pehlivan S, Sever T, Igci M, Arslan A, Orbak R. Association between TNF- $\alpha$, TGF- $\beta 1$, IL- 10 , IL- 6 and IFN- $\gamma$ gene polymorphisms and generalized aggressive periodontitis. Clin Invest Med 2010;33(02):E85-E91

10 Moudi B, Heidari Z, Mahmoudzadeh-Sagheb H, Moudi M. Analysis of interleukin-10 gene polymorphisms in patients with chronic periodontitis and healthy controls. Dent Res J (Isfahan 2018;15 (01):71-79

11 Crena J, Subramanian S, Victor DJ, Gnana PP, Ramanathan A. Single nucleotide polymorphism at -1087 locus of interleukin- 10 gene promoter is associated with severe chronic periodontitis in nonsmoking patients. Eur J Dent 2015;9(03):387-393

12 Heidari Z, Mahmoudzadeh-Sagheb H, Hashemi M, Ansarimoghaddam S, Moudi B, Sheibak N. Association between IFN- $\gamma+874-$ $\mathrm{A} / \mathrm{T}$ and IFN- $\gamma R 1 \quad(-611 \mathrm{~A} / \mathrm{G},+189 \mathrm{~T} / \mathrm{G}$, and $+95 \mathrm{C} / \mathrm{T})$ gene polymorphisms and chronic periodontitis in a sample of Iranian population. Int J Dent 2015;2015:375359

13 Holla LI, Hrdlickova B, Linhartova P, Fassmann A. Interferon- $\gamma$ $+874 \mathrm{~A} / \mathrm{T}$ polymorphism in relation to generalized chronic periodontitis and the presence of periodontopathic bacteria. Arch Oral Biol 2011;56(02):153-158

14 Maulani C, Masulili SLC, Priyadharsini S, Susmiarsih TP, Auerkari EI. Positive correlation between the level of interferon-gamma and the severity of periodontitis. Pesqui Bras Odontopediatria Clin Integr 2019;19:e5106

15 Ramadan DE, Hariyani N, Indrawati R, Ridwan RD, Diyatri I. Cytokines and Chemokines in Periodontitis. Eur J Dent 2020;14 (03):483-495

16 GeneCards. IFNG Gene (Protein Coding) Interferon Gamma. Weizmann Institute of Science Accessed July 12, 2021 at: https://www. genecards.org/cgi-bin/carddisp.pl?gene=IFNG\&keywords=ifng

17 Bream JH, Carrington M, O'Toole S, et al. Polymorphisms of the human IFNG gene noncoding regions. Immunogenetics 2000;51(01):50-58

18 Pravica V, Perrey C, Stevens A, Lee J-H, Hutchinson IV. A single nucleotide polymorphism in the first intron of the human IFNgamma gene: absolute correlation with a polymorphic CA microsatellite marker of high IFN-gamma production. Hum Immunol 2000;61(09):863-866

19 Bream JH, Ping A, Zhang X, Winkler C, Young HA. A single nucleotide polymorphism in the proximal IFN-gamma promoter alters control of gene transcription. Genes Immun 2002;3(03): 165-169

20 Garlet GP, Cardoso CR, Campanelli AP, et al. The essential role of IFN-gamma in the control of lethal Aggregatibacter actinomycetemcomitans infection in mice. Microbes Infect 2008;10(05): 489-496

21 Munk RB, Sugiyama K, Ghosh P, et al. Antigen-independent IFN- $\gamma$ production by human naïve CD4 T cells activated by IL- 12 plus IL18. PLoS One 2011;6(05):e18553

22 Caton JG, Armitage G, Berglundh T, et al. A new classification scheme for periodontal and peri-implant diseases and conditions - Introduction and key changes from the 1999 classification. J Clin Periodontol 2018;45(Suppl 20):S1-S8

23 Jemlia A, Eshilia A, Trifa F, et al. Association of the IFN- $\gamma(+874 \mathrm{~A} / \mathrm{T})$ genetic polymorphism with paranoid schizophrenia in Tunisian population. Immunol Invest 2016;44:1-13

24 Zambon C-F, Basso D, Navaglia F, et al. Pro- and anti-inflammatory cytokines gene polymorphisms and Helicobacter pylori infection: interactions influence outcome. Cytokine 2005;29(04):141-152

25 GBD 2015 Disease and Injury Incidence and Prevalence Collaborators. Global, regional, and national incidence, prevalence, and years lived with disability for 310 diseases and injuries, 19902015: a systematic analysis for the global burden of disease study 2015. Lancet 2016;388(10053)1545-1602

26 Jepsen S, Caton JG, Albandar JM, et al. Periodontal manifestations of systemic diseases and developmental and acquired conditions: consensus report of workgroup 3 of the 2017 World Workshop on the Classification of Periodontal and Peri-Implant Diseases and Conditions. J Clin Periodontol 2018;45(Suppl 20):S219-S229

27 Laine ML, Loos BG, Crielaard W. Gene polymorphisms in chronic periodontitis. Int J Dent 2010;2010:324719

28 Shi Q Cai C, Xu J, Liu J, Liu H, Huo N. Is there an association between IFN- $\gamma+874 \mathrm{~A} / \mathrm{T}$ polymorphism and periodontitis susceptibility?: a meta-analysis Medicine (Baltimore) 2017;96(25): e7288

29 Babel N, Cherepnev G, Babel D, et al. Analysis of tumor necrosis factor-alpha, transforming growth factor-beta, interleukin-10, IL6 , and interferon-gamma gene polymorphisms in patients with chronic periodontitis. J Periodontol 2006;77(12):1978-1983

30 Huang HR, Zhong YQ Wu JF. The association between IFN- $\gamma$ and IL-4 genetic polymorphisms and childhood susceptibility to bronchial asthma. Gene 2012;494(01):96-101

31 Heidari Z, Moudi B, Mahmoudzadeh-Sagheb H. Immunomodulatory factors gene polymorphisms in chronic periodontitis: an overview. BMC Oral Health 2019;19(01):29 